\title{
Cultivating University Teachers' Innovative Work Behavior: The Case of Pakistan
}

\author{
Hina Shahab ${ }^{1}$, Rabia Imran ${ }^{2}$
}

\begin{abstract}
This research focuses on identifying the role of ethical work context (EWC) along with internal social capital (SC) in creation of innovative work behavior (IWB) among teachers in Higher education institutions across Pakistan. Data from 724 faculty members from various public/private universities were analyzed in relation to ethical work context, internal social capital and innovative work behavior. It was identified that ethical work context had a direct impact on innovative work behavior. Furthermore, social capital played significant role in creation of innovative work behavior and also work as mediator between ethical work context and innovative work behavior.
\end{abstract}

Keywords: Ethical work context, social capital, innovative work behavior, higher educational faculty members

\section{Introduction}

Innovation plays crucial role in promotion of economic development for any country. It not only ensures economic growth but also helps in gaining sustainable competitiveness (Zhu, 2015).

All those countries who are striving for efficient economy are heavily investing in cultivation of knowledge, skills and the competencies of their people mainly educators at the universities. These qualified and the experienced faculty members are primarily the knowledge and innovation drivers of any society (Blaskova, Blasko, Matuska \& Rosak-Szyrocka, 2015).

Ozturk and Bayrak (2015) also identified a strong positive correlation between the development level of a country and the quality number of its universities. Their study showed that strong relationship exists between most developed countries and their placement among the top 500 universities of the world.

1 PhD Scholar, SZABIST. Islamanad.Email: hina.shahab@gmail.com

2 Associate Professor, Dhofar University, Salalah, Oman. Email: rabiaimran@yahoo.com

\begin{tabular}{lll} 
ARTICLE HISTORY & & \\
31 Oct, 2017 Submission Received & 10 Dec, 2017 & First Review \\
\hline 12 Dec, 2017 Second Review & 20-Dec-17 & Revised Version of Both Reviews \\
\hline 15 Jan, 2018 Accepted & &
\end{tabular}


According to Times Higher Education (THE) World University Ranking, recently 300 universities have emerged as the strong quality providing institutions situating in 24 different Asian countries. Since last year there is dramatic inclusion of 100 more higher education institutions. This new inclusion revealed the emergence of South Asian countries like Malaysia, Indonesia and Pakistan in becoming prospective strong players for providing quality higher education. Today Pakistan has improved its ranking by having the top seven of its higher educational institutions getting placed among top 300 ranking but still there is long way to go (Kanwal, 2017).

In order to gain sustained competitive advantage the higher education commission (HEC) of Pakistan is focused towards improving Higher Educational Institutions' (HEI's) teaching and research quality culture. Their main focus is towards building the faculty innovative behavior which is not just based on establishing teaching and learning strategies but also focused towards academic and practical research of the educational institutions (Mahmood, 2016).

The above discussion highlights the contextual importance of studying innovative work behavior in HEI's in Pakistan. Similarly, the importance of Innovative work behavior (IWB) can be identified by its impact on enhancing the employees work role performance (leong \& Rasli, 2014) and generation of innovative outputs such as competitiveness (Sulaiman, 2015; Aslam, Aslam \& Ismail, 2017).

In past, the individual level variables such as transformative leadership (Pieterse, Van Knippenberg, Schippers, \& Stam, 2010), self efficacy (Hsio, Cheng, Tu \& Chen, 2011) proactive goal planning (Montani, Odardi \& Battistelli, 2014) and organizational level variables such as organizational justice (Akram, Haider \& Feng, 2017), positive organizational support (Yuan \& Woodman, 2010) and Job Autonomy (Spiegelaere, Gyes, Witte, Niesen, \& Hootegem, 2014) have been discussed in literature as the antecedents of the Innovative work behavior. Whereas the variables like Job engagement (Spiegelaere et al., 2014), employee commitment and employee trust (Lee, 2014) were previously studied as the intervening variables in relation to IWB.

However, in this study the antecedents of innovative work behavior are derived from social exchange theory (SET) which explicate that the employment relationship are maintained between the employees and their organization in order to gain mutual benefits (Blau, 1964). The starting point of SET is based on norm of reciprocity which is the most elementary rule behind governing the human behavior (Gouldner, 1960). Secondly, trust is the manifestation of social exchange, which underpins mutual loyalty, goodwill and support. Employee perception of ethics and justice makes organization trustworthy and enables the employee to take risk to the extent at which he /she feels psychologically safe and trusted. From this mutual trust building relationship 
will create social networks for exchanging knowledge (Cropanzano \& Mitchell, 2005) and from this sharing and transfer of knowledge will ultimately generate innovative work behavior.

This study is important because it theoretically contributes to the body of knowledge by identifying the Ethical work context as the new organizational level antecedent of Innovative work behavior. This relation is based on the suggestions given by Daft, Murphy and Wilmott (2010) who strongly emphasized that the organizations which demands for innovative outputs required horizontal authority based on organic and flexible structures, shared information systems and high degree of ethically collaborative work contexts. Similarly, the social exchange theory (SET) also supports this relationship by considering reciprocal exchange rule proposition which justifies that the positive behavior of one party (Employees innovative work behavior) is dependent on the benefitting behavior/ action (Ethical work context) of the other party (Kelley \& Thibault, 1978).

Secondly, another important theoretical contribution of this study is identifying the new path role of social capital as the mediator between ethical work context and innovative work behavior. The previous studies already established that in order to generate innovative work behavior the social capital is necessarily required (June \& Kheng, 2014; Akram, Li, Haider \& Feng, 2017) and cultivation of social capital is dependent on Ethical work context (Pastoriza, Aríño \& Ricart, 2009; Pastoriza, Arino, Ricart, \& Canela, 2014). These studies help in formulating the rationale that social capital can potentially work as the mediator between ethical work context and innovative work behavior. Further, this relationship is also supported while keeping in view social exchange theory proposition which states that strong relationship networks are required for the prevalence of positively benefitting exchanges at workplace (Cropanzano \& Mitchell, 2005). This SET proposition also justifies that strong network such as social capital is essential between consistent organizational (ethical work context) and employees (innovative work behavior) exchanges.

\section{Theoretical Framework/Literature Review}

Employees innovative work behavior today is considered as the strongest asset in gaining competitive advantage for the organizations. Similarly, creation of new knowledge and development of competitive culture at higher educational institutions resides on teachers innovative work behavior (Blaskova, Blasko, Figurska \& Sokol, 2015). This study follows Janssen (2000) definition for explaining innovative work behavior (IWB) concept as the intentional creation by introducing and applying new ideas within work at individual, group or organizational level for the purpose of achieving shared benefits. This definition was operational zed into three phases 
1) idea generation which is based on brain storming and problem solving, 2) idea promotion which mainly sharing of ideas on formal platforms and 3) idea realization means application of ideas and converting them into reality.

Thurlings, Evers and Vermeulen (2014) also highlighted the significance of teachers innovative work behavior by advocating three main reasons. First, it helps the educators in keeping themselves up to date with dynamic changes in the society. Secondly, it facilitates new learning and technologies. Thirdly, in order to create a competitive society teacher's innovative work behavior is the starting point for developing citizens as creative and innovative thinkers.

\subsection{Ethical work context}

Pastoriza et al. (2009) defined "ethical work context" as the set of managerial practices which are practiced in organization for a long time period and that cannot be changed overnight. These practices are based on 1) fairness and transparency in the access towards the resources, 2) management involving the members in collective decisions that are affecting them, 3) providing open and frequent feedback to all the employees, 4) establishing the clear SoP's standards of practices for the required behavior, and 5) authorizing members based on credibility and consistency which is controlled by the top management for the purpose of creating the work ethic in the organization.

While looking reviewing literature, HR systems (Preito \& Perez-santana, 2014) and managerial practices (Odoardi, Montani, Boudrias \& Battistelli, 2015) were studied as the predecessor for generating innovative work behavior. However, the research lacks empirical evidence while investigating ethical work context in relation to innovative work behavior.

Although Pastoriza et al. (2014) discussed that ethical work context instills the sense of ownership and belonging among employees that can compels them in returning positive gestures or behaviors. So it is expected that ethical work context leads to employees innovative work behavior.

H1: There is a positive effect of Ethical work context on Innovative Work Behavior

Pastoriza et al. (2014) indicated that ethical work context plays a very significant role it builds the network of trust among the organizational members to share their resources and information and also fosters the mutual understanding among employees for achieving collective goals for the organization. Thus ethical work context can be main contributor in creation of organizational internal social capital. 
Jiang and Probst (2017) identified that management who applies uniformly fair and equitable set of policies and procedures across the entire organization develop trust among their employees and in return it facilitate the development of cooperative context and collaborative behaviors (social capital). This strongly advocates the social exchange assumption that the positive and kind exchanges ensured by the organizations results into strong collaborative relationships.

This study is important as it will help in generalizing the role of ethical work context in creation of social capital.

H2: There is a positive effect of Ethical work context on Social Capital

\subsection{Social capital}

Leena and Pil (2006) explained that social capital is based on three important dimensions. They are 1) structural capital explained as people interactions and connections; 2) relational capital is based on trust and quality of relationships which people develop over a period of time, 3) cognitive capital means collective understanding of shared or common goals among member of the organization.

This study uses teacher's social capital, defined as the groups or networks of teachers, formulated for the purpose of teacher learning and support in new knowledge development and its dissemination and transfer (Herzog, Ripple \& Lannuccilli, 2015).

Social capital in the universities can be based upon two dimensions that are internal and external social capital (Leena \& Pil, 2006). The internal social capital of universities can be constructed into formal networks that are created by the university administration to encourage group learning and sharing across all departments within the universities (Fox \& Wilson, 2015; Schwarz \& Caduri, 2016; Willegems, Consuegra, Struyven \& Engels, 2017) and can be based informal networks that are formed by faculty and staff by mutual exchange relationships and trust developed over the period of time (Nolan \& Molla, 2017). Similarly, the external social capital in universities can also be formal (Maietta, 2015; Clauss \& Kesting, 2017) networks that comprises of university and industry or other stakeholders linkages outside the universities and can be also be based on informal (Trust, Krutka \& Carpenter, 2016; Quinn, 2016; Rehm \& Notten, 2016) networks based on faculty informal collaborations outside the universities in teaching communities (social media and twitters). Though, all these dimensions and types of social capital prevailing in the universities are imperative in knowledge sharing as well as development. However, the present research is focused upon the role of internal social capital based on both informal and formal networking and collaborations among the teachers within their universities. The selection of the internal social capital is due to the reason that it primarily focuses 
upon the generation of innovation driven 'behavior' aspect of a teacher within the university (Nollan \& Molla, 2017).

Organizational social capital in relation with innovative work behavior has theoretically been focus of discussion among researchers. However, Akram et al. (2017) recently conducted the study and identified that keeping in view exchange theory social capital plays significant role in developing innovative work behavior. People feel responsibility to share knowledge or tend to reciprocate when they have good mutual exchange relationships and this eventually generate innovative work behaviors by employees in the organization (Cropanzano \& Mitchell, 2005).

This paper contributes towards further generalizing the significance of internal social capital in creation teachers innovative work behavior especially in eastern context of Pakistan.

H3: There is a positive effect of Social Capital on Innovative Work Behavior

Based on social exchange theory (Cropanzano \& Mitchell, 2005) which suggest that consistent positive exchanges requires trust based networks encourage this study to investigate the mediating role of social capital between ethical work context and innovative work behavior.

Similarly, when employees trust that their organizational management systems are ethical and clearly defined standard operating procedures prevails to give credit on their performances then the employees are more likely engaged in social networking for sharing of their ideas and information and that can result in generation of their innovative work behavior.

H4: Social Capital mediates the relationship between Ethical work context and Innovative Work Behavior.

\section{Methodology}

\subsection{Partici pants}

Higher education faculty members from various public and private universities responses were collected from all five regions of Pakistan. The response gathered from federal region was 482, from Punjab 75, Sindh 94, KPK 38, Baluchistan 18 and AJK 17. The majority of responses were gathered from federal region as all public and private universities were targeted. However (public and private) universities from other regions were also selected on the basis of personal accessibility in order to capture general perception by faculty members in higher education institutions all over Paki- 
stan. 1500 questionnaires were floated in various universities across Pakistan out of which 850 questionnaires were returned back from which 126 questionnaires were discarded due to incomplete data. The total usable feedback response rate was $48.2 \%$ out of which 376 were males and 348 were female respondents. Among them 371 were Lecturers, 248 were Assistant Professors, 52 were Associate Professors and 53 were Professors.

The reason for selecting higher education sector because recently HEC is stressing towards invoking and promoting more research based culture among universities in order to train, develop and open up new state of the art avenues to improve teachers innovative capabilities and performance so that they can envision future and contribute in the long-term institutions building process of Pakistan.

\subsection{Procedure}

The deductive approach has been used in present study based on cross sectional time horizon. So in order to prove the pre-existing theory the deductive method is the most common approach (Silverman, 2013). The data has been collected through the administration of a comprehensive survey questionnaire which was personally delivered or through post to the researcher's acquaintances by applying non probability snowball sampling technique. This survey strategy is generally used in cross sectional data when collecting data from large no. of population and direct accessibility to population is difficult (Cohen \& Arielei, 2011). As the data was collected from all five regions of Pakistan and it was researcher constraint to visit all regions. Secondly the no. of faculty was also not known to the researcher so snowball sampling technique was most desirable for research.

\subsection{Instruments and measures}

The central variables of this study are Innovative work behavior (IWB), ethical work context (EWC) and social capital (SC).

The dependent variable Innovative work behavior (IWB) was measured by adapting the scale of Janssen (2000) using 6 items based on three dimensions that were idea generation (IG), idea promotion (IP) and idea realization (IR). The independent variable ethical work context (EWC) was adapted from Pastoriza et al. (2014) by combining two dimensions into composite 10 items scale. The mediating variable internal social capital (SC) was measured by adapting the scale of Leena and Phil (2006) using 15 items based on three dimensions such as Structural social capital (SSC), Relational social capital (RSC), Cognitive social capital (CSC). All the variables were measured on five-point likert scale starting with 1 as "Strongly Disagree", 2 as "Disagree", 3 as 
"Neutral", 4 as "Agree" and 5 as "Strongly Agree".

The demographic variables like Gender, Age, Experience and Designation etc were tested on dependent variable and showed insignificant effect on dependent variable, thus can be treated as control variables.

\section{Analysis and Results}

This section comprised on two parts for testing hypothesized model. First part is related to descriptive statistics, validity, reliability and unidimensionalty of the measurement model of all the constructs. The second part is based on structural validation of direct and indirect effect of the model suggested by Byrne (2001).

\subsection{Preliminary analysis}

In the preliminary analysis, descriptive statistics along with discriminant validity are displayed in Table I. The descriptive analysis shows first the variables mean values ranges from 3.5 to 3.8 where as standard deviations lies from .59 to .65 and for checking data normality the skewness and kurtosis values exist in the acceptable range $(-3$ to +3 ) according to Ghasemi and Zahediasl (2012). Secondly, the correlations among variables were moderate and all constructs relation exists below 0.9 which indicate that multicollinearity will not be the issue in this study (Tabachnick \& Fidell, 2001). However, in order to further rule out the chance of prevalence of multicollinearity, tolerance and variance inflation were also checked. EWC tolerance was .580 with VIF 1.725, for SC tolerance .549 with VIF 1.823. The data indicated that multicollinearity was not an issue as all tolerance values are $>.1$ and all VIF values are $<10$ (Hair, Black, Babin, \& Anderson 2009).

Table 1: Means, Standard Deviation, Skewness, Kurtosis, Correlations \& Discriminant Validity

\begin{tabular}{|c|c|c|c|c|c|c|c|c|}
\hline Scales & $\begin{array}{c}\text { Mean } \\
(\text { SD) }\end{array}$ & $\begin{array}{c}\text { Skewness Std. } \\
\text { Error (.091) }\end{array}$ & $\begin{array}{c}\text { Kurtosis Std } \\
\text { Error (.181) }\end{array}$ & 1 & 2 & 3 & 4 & 5 \\
\hline 1 & IWB & $3.83(.656)$ &. .586 & -.131 & $(.767)$ & & & \\
\hline 2 & SC & $3.55(.632)$ &. .197 &. .595 & $.594^{* *}$ & $(.784)$ & & \\
\hline 3 & EWC & $3.55(.598)$ &. .195 & -.561 & $.454^{* *}$ & $.615^{* *}$ & $(.728)$ & \\
\hline
\end{tabular}

IWB= Innovative work behavior, $\mathrm{SC}=$ Social capital, $\mathrm{EWC}=$ Ethical work context

Note. The values in parenthesis represents square root of AVE of every construct

**. Correlation is significant at the 0.01 level (2tailed). 
Secondly, Discriminant validity was also conducted which is the square root of Average variance extracted (AVE) for each construct which should be greater than values of the inter-construct correlations between the groups of constructs/variables. The purpose of conducting discriminant validity is to investigate that the independent variables are distinct of each other while measuring the change in dependent variable (Hatcher, 1994). Table I. indicated that square root of AVE is higher for all the variables than their correlation coefficient values with others.

For convergent validity Average variance extracted (AVE) and CFA was conducted. The AVE values were calculated by using the Hair, Black, Babin, Anderson, and Tatham (2006) formula. Sweeney and Soutar (2001) established that the score of AVE $<.50$. All values of AVE are above .5. in Table II. The convergent validity was further assessed through CFA which reflects through the significant factor loading $>.50$ according to Hu and Bentler (1999). In the Table II all factor loadings are above .50 which shows a strong convergent validity of the variables. Similarly, for reliability of scales Cronbach alpha for each of the construct was measured. The results reported in

Table 2: Convergent Validity, Reliability and Unidimensionality

\begin{tabular}{|c|c|c|c|c|c|c|c|}
\hline Variables & $\begin{array}{c}\text { Dimen- } \\
\text { sions }\end{array}$ & $\begin{array}{c}\text { Square Multiple } \\
\text { Correlations (SMC) }\end{array}$ & CFI & \begin{tabular}{|c|} 
Standardized Factor- \\
Loadings (St. FL) \\
\end{tabular} & IC & $\mathrm{CR}$ & AVE \\
\hline \multirow{3}{*}{$\begin{array}{c}\text { Innovative } \\
\text { Work } \\
\text { Behavior } \\
\end{array}$} & IG & .512 & \multirow{3}{*}{1.00} & .76 & \multirow{3}{*}{.824} & \multirow{3}{*}{.811} & \multirow{3}{*}{.589} \\
\hline & IP & .668 & & .82 & & & \\
\hline & IR & .573 & & .72 & & & \\
\hline \multirow{3}{*}{$\begin{array}{l}\text { Social } \\
\text { Capital }\end{array}$} & SSC & .621 & \multirow{3}{*}{1.00} & .72 & \multirow{3}{*}{.915} & \multirow{3}{*}{.827} & \multirow{3}{*}{.616} \\
\hline & RSC & .714 & & .84 & & & \\
\hline & $\mathrm{CSC}$ & .516 & & .79 & & & \\
\hline \multirow{10}{*}{$\begin{array}{l}\text { Ethical } \\
\text { Work } \\
\text { Context }\end{array}$} & D1 & .584 & \multirow{10}{*}{.981} & .77 & \multirow{10}{*}{.917} & \multirow{10}{*}{.919} & \multirow{10}{*}{.728} \\
\hline & D2 & .489 & & .73 & & & \\
\hline & D3 & .543 & & .71 & & & \\
\hline & D4 & .521 & & .73 & & & \\
\hline & D5 & .482 & & .71 & & & \\
\hline & D6 & .500 & & .69 & & & \\
\hline & D7 & .535 & & .72 & & & \\
\hline & $\mathrm{D} 8$ & .507 & & .74 & & & \\
\hline & D9 & .526 & & .70 & & & \\
\hline & D10 & .591 & & .78 & & & \\
\hline
\end{tabular}

Note: IG= Idea Generation, IP= Idea Promotion, IR= Idea Realization, SSC= Structural social capital, $\mathrm{RSC}=$ Relational social capital, $\mathrm{CSC}=\mathrm{Cognitive} \mathrm{social} \mathrm{capital.}$

$\mathrm{CFI}=$ Confirmatory factor analysis, $\mathrm{IC}=$ Internal consistency, $\mathrm{CR}=$ Construct reliability, $\mathrm{AVE}=$ Average variance extracted 
Table II indicated that all internal consistency (IC) and construct reliability (CR) are $>.70$ (Hair et al., 2006). Thus prove internal consistency and reliability of constructs.

Unidimensionality is used to check that the items in a single construct measures that same construct or not (Jackson, Denzee, Douglas \& Shimeall, 2005). In this study the unidimensionality is measured through Confirmatory factor analysis (CFA), Comparative Fit Index (CFI) and Square multiple correlations (SMC). CFA threshold values already confirmed and discussed above in convergent validity. Similarly, CFI which explains the good fit regarding data and specify that the values should be more than 0.90 (Hatcher, 1994). All values of CFI in Table II are above 0.90 indicating good fit of data. Finally, Square multiple correlations were used in order to measure the reliability of the items and to detect the problem creating observed errors. As if the FL values are $<0.50$ along with values of $\mathrm{SMC}<0.20$ of any item than that item needs to be omitted according to the criteria provided by Hu and Bentler (1999). Here, in Table II all values of SMC >.20 and St. FL. >.50 so it proved that no problematic error exist in the data.

\subsection{Common method bias}

Scholars always argued about the existence of common method bias in self reporting data (Conway \& Lance, 2010). In order to detect and control common method bias literature provides many statistical remedies (Chang, Van Witteloostuijn, \& Eden, 2010). In this study Harman's one-factor test has been used to investigate the existence of CMB (Bish, Newton \& Johnstan, 2015). In this study an EFA of

Table 3: One Factor Model (CMV)

\begin{tabular}{|c|c|c|c|c|c|c|}
\hline \multirow{2}{*}{$\begin{array}{c}\text { Compo- } \\
\text { nent }\end{array}$} & \multicolumn{3}{|c|}{ Initial Eigen values } & \multicolumn{3}{c|}{ Extraction Sums of Squared Loadings } \\
\cline { 2 - 7 } & Total & $\begin{array}{c}\% \text { of Vari- } \\
\text { ance }\end{array}$ & $\begin{array}{c}\text { Cumulative } \\
\%\end{array}$ & Total & $\begin{array}{c}\% \text { of Vari- } \\
\text { ance }\end{array}$ & $\begin{array}{c}\text { Cumulative } \\
\%\end{array}$ \\
\hline 1 & 16.180 & 32.361 & 32.361 & 16.180 & 32.361 & 32.361 \\
\hline 2 & 3.817 & 7.634 & 39.994 & & & \\
\hline. &. &. &. & & & \\
\hline. &. &. &. & & & \\
\hline. &. &. &. & & & \\
\hline 48 & .189 & .378 & 99.330 & & & \\
\hline 49 & .175 & .351 & 99.681 & & & \\
\hline 50 & .160 & .319 & 100.000 & & & \\
\hline
\end{tabular}

Note: Extraction Method: Principal Component Analysis. 
all items disclosed 50 factors having the first factor accounting only $32.361 \%$ of the total variance which is less than $50 \%$ of the threshold point that proves that CMV was of no threat to this study.

\subsection{Model evaluation:}

For testing structural equation modeling (SEM) Preacher and Hayes (2008) recommend path analysis method for investigating the mediation process through bootstrapping. In this study two models are tested for mediation process. First Model 1 indicates the direct effect between Ethical work context and innovative work behavior, while the Model 2 indicates the indirect effects. Path coefficients and fit indices are described in Table. IV. The recommended value for (CMIN/DF) Chi-square / degree of freedom is between 2 and 5, for (RMSEA) Root mean square of approximation

Model 4: Model Fit Indices

\begin{tabular}{|c|c|c|c|c|c|c|}
\hline Models & CMIN/DF & GFI & AGFI & NFI & CFI & RMSEA \\
\hline Model 1 & $2.256 / 64$ & .970 & .957 & .970 & .983 & .042 \\
\hline Model 2 & $2.669 / 101$ & .957 & .942 & .957 & .972 & .048 \\
\hline
\end{tabular}

Note. $\mathrm{CMIN} / \mathrm{DF}=$ chi-square/degree of freedom ratio; GFI $=$ goodness of fit index; AGFI $=$ adjusted goodness of fit index; NFI = normed fit index; CFI = comparative fit index; RMSEA = root mean square of approximation.

should be $<.08$, for (GFI) Goodness of fit index, (AGFI) Adjusted goodness of fit index, (NFI) Normed fix index and (CFI) Comparative fit index should be $<0.90$ (Hair et. al, 2006). Table IV indicates that both Model 1 and Model 2 indices proves goodness of fit by fulfilling the model fit threshold indices of CMIN/DF, RMSEA, GFI, AGFI, NFI and CFI.

\subsection{Direct and indirect paths analysis}

While testing the direct path coefficient of Model 1, Ethical work context was positively related to Innovative work behavior with path coefficient .72 and $\mathrm{P}$ value $<.001$. Hence proving H1 supported. While testing Model 2, Social capital was added as mediator between Ethical work context and Innovative work behavior.

The path analysis shows that the Ethical work context has positive direct effect on social capital having the path coefficient .70 with P-value <.001. So H2 was supported. Similarly, the path analysis shows that social capital has a positive direct effect on innovative work behavior by having its path coefficient .45 with P-value <.001. Hence, proving $\mathrm{H} 3$ also supported. 


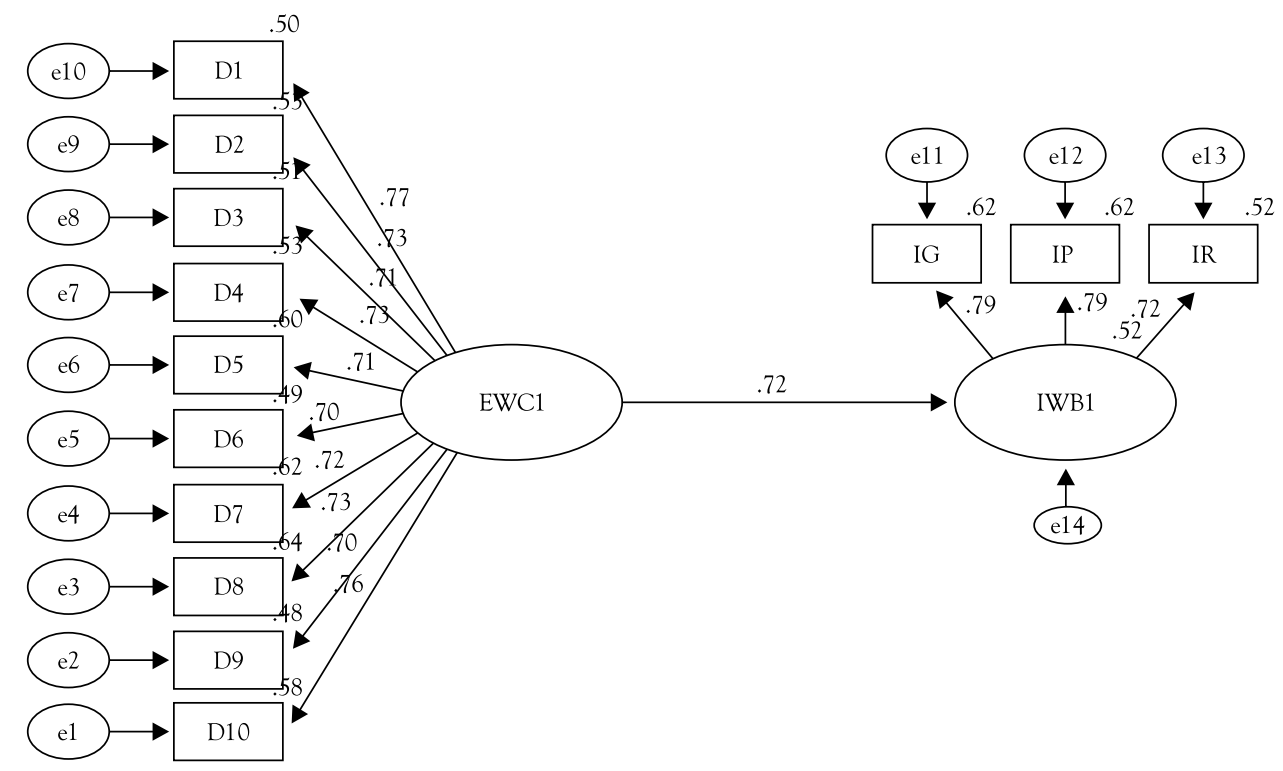

Figure 1. Model 1: Note. EWC1= Ethical work context, IWB1= Innovative work behavior, ${ }^{* * *} \mathrm{p}<.001$

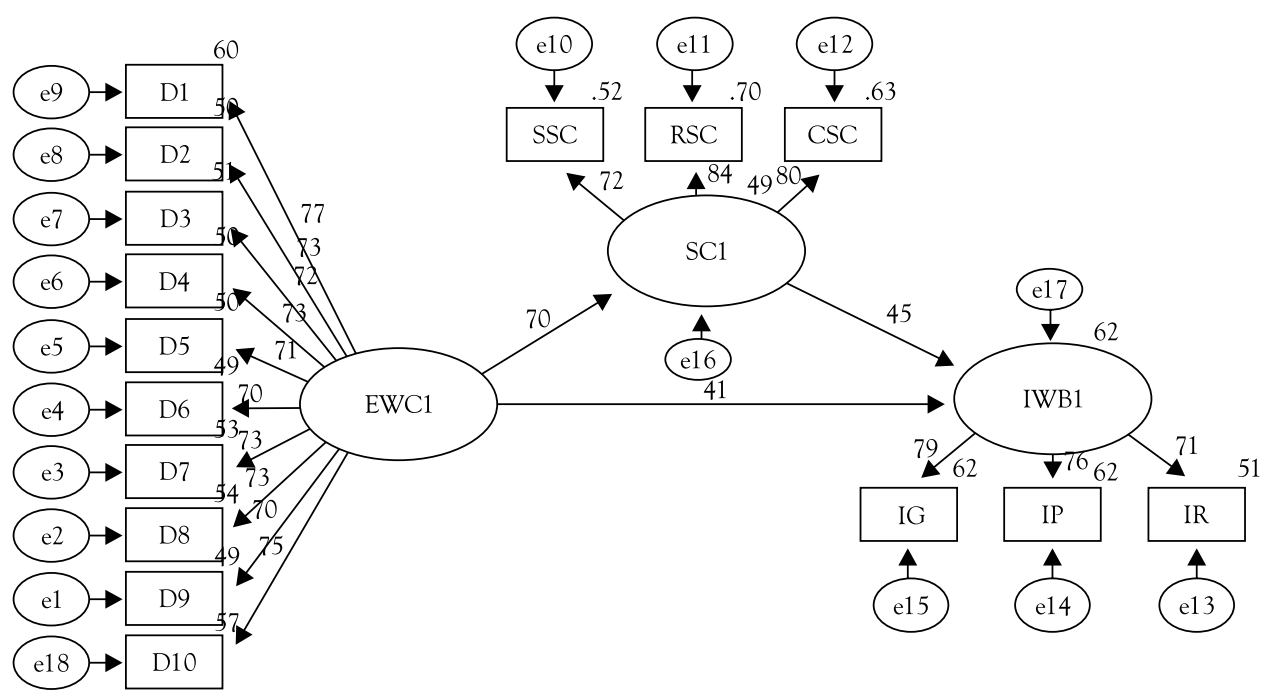

Figure 2. Model 2: Note. EWC1= Ethical work context, IWB1= Innovative work behavior, $\mathrm{SC}=$ Social Capital, ${ }^{* * *} \mathrm{p}<.001$ 
This study also investigates the mediating role of social capital between ethical work context and innovative work behavior. For this purpose Preecher and Hayes (2008) bootstrapping method with 2000 iterations are used to check significance of the indirect effect. The indirect effect of Ethical work context (EWC1) on Innovative work behavior (IWB1) through Social capital (SC1) is having its path coefficient value .31 with two tailed P-value <.001 and the ratio of indirect effect to the total effect is

Table 5: Direct and Indirect Effects

\begin{tabular}{|c|c|c|c|c|c|c|c|}
\hline $\begin{array}{c}\text { Hypoth- } \\
\text { esis }\end{array}$ & $\begin{array}{c}\text { Direct } \\
\text { Effects }\end{array}$ & $\begin{array}{c}\text { Indirect } \\
\text { Effects }\end{array}$ & $\begin{array}{c}\text { Total } \\
\text { Effects }\end{array}$ & $\begin{array}{c}\text { Ratio of } \\
\text { indirect } \\
\text { effect to } \\
\text { the total } \\
\text { effect (\%) }\end{array}$ & \multicolumn{2}{|c|}{$\begin{array}{c}\text { Bias corrected confi- } \\
\text { dence interval }\end{array}$} & Results \\
\cline { 5 - 7 } & & & $\begin{array}{c}\text { Lower } \\
\text { confi- } \\
\text { dence } \\
\text { level }\end{array}$ & $\begin{array}{c}\text { Upper } \\
\text { confi- } \\
\text { dence } \\
\text { level }\end{array}$ & \\
\hline $\begin{array}{c}\text { EWC1 } \\
\text { IWB1 }\end{array}$ & $.72^{* * *}$ & & & & & & $\begin{array}{c}\text { Support- } \\
\text { ed }\end{array}$ \\
\hline $\begin{array}{c}\text { EWC1 } \rightarrow \\
\text { SC1 }\end{array}$ & $.70^{* * *}$ & & & & & & $\begin{array}{c}\text { Support- } \\
\text { ed }\end{array}$ \\
\hline $\begin{array}{c}\text { SC1 } \rightarrow \\
\text { IWB1 }\end{array}$ & $.45^{* * *}$ & & & & & & \\
\hline $\begin{array}{c}\text { EW- } \\
\text { C1 } \rightarrow \text { SC } \\
\text { IWB1 }\end{array}$ & $.42^{* * *}$ & $.31^{* * *}$ & $.72^{* * *}$ & 43.05 & .23 & .39 & $\begin{array}{c}\text { Support- } \\
\text { ed }\end{array}$ \\
\hline
\end{tabular}

Note: EWC1 = Ethical work context, SC1= Social Capital, IWB1= Innovative work behavior, $* * *=\mathrm{P}<0.001$

43\%. Furthermore, the lower confidence level was .23 and the upper confidence level was 39 in Table V. and zero does not exist between lower and upper confidence levels (Yasir, Imran, Irshad, Mohammad \& Khan, 2016) which proves partial mediation does exist. Hence, H4 is also supported.

\section{Discussion}

The findings on this study based on 724 faculty members from public and private universities across Pakistan provided substantial evidence to prove that the ethical work context plays significant role in creation of faculty innovative work behavior in universities. This study is aligned with the research of Pastoriza et al. (2014) and Jiang and Probst (2017) proving the impact of ethical work context on social capital. 
As Pastoriza et al. (2014) discussed that knowledge intensive organizations requires better coordination and communication between employees in order to generate new ideas and collective work for problem resolution. So the employees in knowledge intensive organizations strongly value ethical managerial practices.

Similarly, innovative work behavior in Higher Education Institutions (HEI's) is important. HEI's works as the knowledge intensive hubs and the teachers plays the role of change agents in cultivating new knowledge and information. This study shows that teachers value the Ethical Work Context (EWC) as the supportive mechanism which needs to be given more importance at universities. EWC helps faculty in developing internal social networks through which they learn and engage into research activities, thus ultimately generates their innovative work behavior.

Finally, the major theoretical as well as empirical gap which is covered through this study is the imperative role of social capital as a mediator between ethical work context and innovative work behavior. This study proves that based on social exchange theory (Balu, 1964) perception of ethical work practices by employees does create trust which manifests internal social capital and through this knowledge exchange and transfer occur between organization members resultant in innovative work behavior.

\subsection{Limitations and future directions}

This study is evident in covering important theoretical and empirical gaps still it contains some limitations. This study was cross sectional in nature despite mitigating the occurrence common method bias through CMV technique. In future, longitudinal design could be employed in order to investigate variables relationships over time.

Secondly, it is suggested that the future research should also investigate the moderating effect of internal organizational culture in these relationships. As Adewal and Athonie (2013) explained that the culture works like a DNA in any organization which is though invisible yet have a powerful impact in shaping the behaviors of the members of that organization. So the future research can investigate internal organizational cultures an aiding/ facilitating in implementing ethical work context among employees and help in creating trust based mechanisms such as social capital within the organizations. 


\subsection{Theoretical im plications}

This study adds value to the existing social exchange theory by identifying the role of ethical work context as the important antecedent of innovative work behavior. Hence, it open new avenue of research by identifying the importance of ethics in innovation literature. Furthermore, social capital which so far was studied in literature as the strong antecedent of innovative work behavior has been explored as the mediator in this study which creates new research directions to study the mediating role of social capital between innovative work behavior and its other potential antecedents.

\subsection{Practical implications}

This study is essential in understanding practical role of management in ensuring ethical work practices in their organizations. Ethical work practices not only develop the trust based culture but also important for cultivation of exchange based social networks among employees within their organizations. The formation of such social networks helps in developing employees innovative work behavior that contributes towards organizational competitiveness. Similarly, the faculty innovative work behavior in higher education sector is the true indicator for universities global competitiveness.

Now it is a high time for policy and decision makers in higher education sector (HEC) of Pakistan that in order to improve their university rankings they must assure faculty innovative work behavior. This study addresses the perception of faculty members that their innovative work behavior is dependent on the prevalence of clear ethical mechanisms and internal social networking within their universities.

\section{References}

Akram, T., Lei, S., Haider, M. J., \& Akram, M. W. (2017). What impact do structural, relational and cognitive organisational social capital have on employee innovative work behaviour? A studyfrom china. International Journal of Innovation Management, 21(02), 1-29.

Aslam, H., Aslam, B., Ismail, L., \& Cheema, H. (2017). The effect of employee's innovative work behavior on innovative output. Global Journal of Research in Business $\mathcal{E}$ Management, 6(2), 461-468.

Bish, A., Newton, C., \& Johnston, K. (2015). Leader vision and diffusion of HR policy during change. Journal of Organizational Change Management, 28(4), 529-545.

Bishop, J. W., Scott, K. D., \& Burroughs, S. M. (2000). Support, commitment, and employee outcomes in a team environment. Journal of Management, 26(6), 1113-1132. 
Blaskova, M., Blasko, R., Figurska, I., \& Sokol, A. (2015a). Motivation and development of the university teachers' motivational competence. Procedia-Social and Behavioral Sciences, 182, 116-126.

Blaskova, M., Blasko, R., Matuska, E., \& Rosak-Szyrocka, J. (2015b). Development of key competences of university teachers and managers. Procedia - Social and Behavioral Sciences, 182, 187 - 196

Blau, P. (1964). Exchange and power in social life. New York, NY: Wiley

Byrne, B. M. (2001). Multivariate applications book series. Structural equation modeling with AMOS: Basic concepts, applications, and programming. Mahwah, NJ: Lawrence Erlbaum Associates.

Chang, S.-J., Van Witteloostuijn, A., \& Eden, L. (2010). From the editors: common method variance in international business research. Journal of International Business Studies, 41,178-184.

Chitrao, P. (2014). Management education as a tool for developing and sustaining emerging economies. Procedia - Social and Behavioral Sciences, 133, 240 - 248

Clauss, T., \& Kesting, T. (2017). How businesses should govern knowledge-intensive collaborations with universities: An empirical investigation of university professors. Industrial Marketing Management, 62, 185-198.

Conway, J. M., \& Lance, C. E. (2010). What reviewers should expect from authors regarding common method bias in organizational research. Journal of Business and Psychology, 25, 325-334

Cropanzano, R., \& Mitchell, S. M., (2005). Social exchange theory: An interdisciplinary review. Journal of Management, 31(6), 874-900.

Daft, R., L., Murphy J., \& Willmott, H. (2010). Organization theory and design. Cengage Learning, Boston, MA

Fox, A. R. C., \& Wilson, E. G. (2015). Networking and the development of professionals: Beginning teachers building social capital. Teaching and Teacher Education, 47, 93-107

Ghasemi, A., \& Zahediasl, S. (2012). Normality tests for statistical analysis: A guide for non- statisticians. Int J Endocrinol Metab, 10(2), 486-489

Gul, A., \& Ahmad, A. (2012). Perspectives of academia-industrial linkage in Pakistan: An insight story. Sci., Tech. and Dev., 31(2), 175-182

Gür, U., Oylumlu, S. I., \& Kunday, O. (2016). Critical assessment of entrepreneurial and innovative universities index of Turkey: Future directions. Technological Forecasting $\mathcal{E}$ Social Change, 18662, 1-8

Haider, M. (2016). Pakistan's ranking in global competitiveness index improves. Available at https://www. thenews.com.pk/print/153314-Pakistans-ranking-in-GlobalCompetitiveness- Index-improves/

Hair, J. F., Black, W. C., Babin, B. J., Anderson, R. E., \& Tatham, R. L. (2006). Multivariate data analysis. Upper Saddle River, NJ: Pearson Prentice Hall 
Hair, J. F., Black, W.C., Babin, B.J., \& Anderson, R. E. (2009). Multivariate Data Analysis. Upper Saddle River, NJ: Pearson Prentice Hall

Hsiao, H. C., Tu, Y. L., Chang, J. C., \& Chen, S. C. (2011). The influence of teachers' self-efficacy on innovative work behavior. Int. Proc. Econ. Dev. Res, 5(1), 233-237.

Hamid, A. R. M., Abdullah, M., Mustafa, Z., Zainal Abidin, B. B. N., \& Ahmad, H. (2015). Conceptual framework of innovation excellence model for higher education institutions. Procedia - Social and Behavioral Sciences, 174, $2846-48$

Herzog, L., Ripple, F. E., \& Lannuccilli, T. L. (2015). Teacher networks in Philadelphia: Landscape, engagement, and value. Perspectives on Urban Education, 12(1), 1-17

Hatcher, L. (1994). A step-by-step approach to using the SAS system for factor analysis and structural equation modeling. SAS Publishing

Hu, L. T., \& Bentler, P. M. (1999). Cutoff criteria for fit indexes in covariance structure analysis: conventional criteria versus new alternatives. Structural Equation Modeling: A Multidisciplinary Journal, 6(1), 1-55.

Jackson, J. L., Denzee, K., Douglas, K., \& Shimeall, W. (2005). Introduction to structural equation modeling: path analysis. Available at http://www.sgim.org/userfiles/file/AMHandouts/AM05/handouts/ PA08.pdf.

Janssen, O. (2000). Job demands, perceptions of effort-reward fairness and innovative work behavior. Journal of Occupational and Organizational Psychology, 73(3), 287-302

Jiang, L. M., \& Probst, T. (2015). Do your employees (collectively) trust you? The importance of trust climate beyond individual trust. Scandinavian Journal of Management, 31, 526-535

Kanwal, M. (2017). Asia University Rankings 2017: 7 Pakistani Institutions make it to top 300. Available at https://www.techjuice.pk/asia-university-rankings-2017-7-pakistani-institutions-make-it-to-top-300/

Kelley, H. H., \& Thibault, J. W. (1978). Interpersonal relationships: A theory of interdependence. New York: John Wiley.

Kwok, P. (2014). The role of context in teachers' concerns about the implementation of an innovative curriculum. Teaching and Teacher Education, 38, 44-55

Leana, C. R., \& Pil, F. K. (2006). Social capital and organizational performance: Evidence from urban public schools. Organization Science, 17(3), 353-366

Leong, T.C., \& Rasli, A. (2013). The Relationship between innovative work behavior on work role performance: An empirical study. Procedia - Social and Behavioral Sciences, 129, 592 - 600

Odardi, C., Montani, F., Boudria, S. J., \& Battistelli, A. (2015). Linking managerial practices and leadership style to innovative work behavior: The role of group and psychological processes. Leadership E Organization Development Journal, 36(5), 545-569 
Oitu, I. L., Ungureanu, R., \& Rusu, C. (2014). European partnership for teacher training in Universities. Procedia - Social and Behavioral Sciences, 142, 200-206

Ozturk, F., \& Bayrak, T. (2015). The academicians' perspective on the challenges facing higher education in turkey. Procedia - Social and Behavioral Sciences, 195, 202 - 209

Mahmood, K. (2016). Overall assessment of higher education sector. Higher Education Commission of Pakistan

Maietta, W. O. (2015). Determinants of university-firm R\&D collaboration and its impact on innovation: A perspective from a low-tech industry. Research Policy, 44, 1341-1359

Nolan, A., \& Molla, T. (2017). Teacher confidence and professional capital. Teaching and Teacher Education, $62,10-18$

Park, J., \& Lee, J. (2013). Knowledge sharing in information systems development projects: Explicating the role of dependence and trust. International Journal of Project Management. 20, 153-165

Pastoriza, D., Aríño A., M., \& RicartSource, E., J., (2009). Creating an ethical work context: A pathway to generate social capital in the firm. Journal of Business Ethics, 88(3), 477-489

Pastoriza, D., Arino, A., M, Ricart, E., J, \& Canela, A. M. (2014). Does an ethical work context generate internal social capital? Journal of Business Ethics, 118(1), 1-12.

Pieterse, N. A., Knippenberg, V.D., Schippers, M., \& Stam, D., (2010). Transformational and transactional leadership and innovative behavior: The moderating role of psychological empowerment. Journal of Organizational Behavior, 31, 609-623

Preacher, K. J., \& Hayes, A. F. (2008). Asymptotic and resampling strategies for assessing and comparing indirect effects in multiple mediator models. Behavior Research Methods, 40, 879-891

Preito, M. I., \& Perez-santana, P. M. (2014). Managing innovative work behavior: the role of human resource practices. Personnel Review, 43(2), 184-208

Quinn, K. (2016). Contextual social capital: Linking the contexts of social media use to its outcomes. Information, Communication $\mathbb{E}$ Society, 19(5), 582-600

Rehm, M., \& Notten, A. (2016). Twitter as an informal learning space for teachers! The role of social capital in twitter conversations among teachers. Teaching and Teacher Education, 60, 215-223

Schwarz, B. B., \& Caduri, G. (2016). Novelties in the use of social networks by leading teachers in their classes. Computers and Education, 102, 35-51

Silverman, D. (2013). Doing qualitative research: A practical handbook. SAGE Publications Limited.

Spiegelaere, D. S., Gyes, V. G., Witte, D. H., Niesen, W., \& Hootegem, V. G. (2014). On the relation of job insecurity, job autonomy, innovative work behavior and the mediating effect of work engagement. Creativity and Innovation Management, 23(3), 318-30 
Suliman, A. (2013). Organizational justice and innovation in the workplace: The case of the UAE. Journal of Management Development, 32(9), 945-959.

Sweeney, C. J., \& Soutar, N. G. (2001). Consumer perceived value: The development of a multiple item scale. Journal of Retailing, 77, 203-220

Tabachnick, B. G., Fidell, L. S., \& Osterlind, S. J. (2001). Using multivariate statistics. New York: Pearson.

Taylor, A. L. (2017). How teachers become teacher researchers: Narrative as a tool for teacher identity construction. Teaching and Teacher Education, 61, 16-25

Trust, T., Krutka, G. D., \& Carpenter, P. F. (2016). Together we are better: Professional learning networks for teachers. Computers $\mathcal{E}$ Education, 102, 15-34

Thurlings, M., Evers, T. A., \& Vermeulen, M. (2015). Toward a model of explaining teachers' innovative behavior: A literature review. Review of Educational Research, 20(10), 1-42

Von Nordenflycht, A. (2010). What is a professional service firm? Towards a theory and taxonomy of knowledge intensive firms. Academy of Management Review, 35(1), 155-174

Walder, M. A. (2016). Pedagogical Innovation in Canadian higher education: Professors' perspectives on its effects on teaching and learning. Studies in Educational Evaluation, 623, 1-12

Willegems, V., Consuegra, E., Struyven, K., \& Engels, N. (2017). Teachers and pre-service teachers as partners in collaborative teacher research: A systematic literature review. Teaching and Teacher Education, 64, 230-245

Yasir, M., Imran, R., Irshad, K. M., Mohamad, A. N., \& Khan, M. M. (2016). Leadership styles in relation to employees' trust and organizational change capacity: Evidence from non-profit organizations. SAGE Open, 6(4), 1-12

Yidong, T., \& Xinxin, L. (2013). How ethical leadership influence employees' innovative work behavior: A perspective of intrinsic motivation. Journal of Business Ethics, 116, 441-455

Yilmaz, O., \& Bayraktar, M. D. (2014). Teachers' attitudes towards the use of educational technologies and their individual innovativeness categories. Procedia - Social and Behavioral Sciences, 116, 3458 - 3461

Yuan, F., \& Woodman, W., R. (2010). Innovative behavior in the workplace: The role of performance and image outcome expectations. Academy of Management Journal, 53(2), 323-342.

Zhu, C. (2015). Organizational culture and technology-enhanced innovation in higher education. Technology, Pedagogy and Education, 24(1), 65-79 
